http://dx.doi.org/10.18232/alhe.948

Artículos

\title{
Las oficinas de la aduana y resguardo del puerto de Rosario en tiempos de la Confederación Argentina, 1852-1854
}

\section{The Offices of the Customs and Safeguard of the Port of Rosario at the Time of the Argentine Confederation, $1852-1854$}

Evangelina de los Ríos ${ }^{* 1}$ (iD 0000-0002-6937-5981

${ }^{1}$ Consejo Nacional de Investigaciones Científicas y Técnicas, Investigaciones Socio Históricas Regionales, Rosario, Argentina

* Correspondencia: eddelosrios@hotmail.com

Resumen. Durante los primeros años de la Confederación Argentina (1852-1862), las oficinas de aduanas y resguardo del puerto de Rosario tuvieron cambios en el ámbito fiscal a partir de la emergencia de una entidad nacional con capacidad para cobrar impuestos. Se inicia con la hipótesis de que el proceso de nacionalización de los recursos y el traspaso de dichas oficinas conllevó numerosos problemas. Este estudio persigue dos objetivos: observar las transformaciones en el interior de dichas oficinas de Hacienda en su paso de la esfera provincial a la confederacional y analizar cómo esta nueva situación afectó las tareas cotidianas de quienes desempeñaban sus labores en estos espacios. En este sentido, se profundiza en las tensiones que surgieron en estas dependencias al gestionar diferentes potestades fiscales.

Palabras clave: aduana; finanzas; Rosario; Confederación Argentina.

Abstract. During the first years of the Argentine Confederation (1852-1862), the customs and safeguard offices of the port of Rosario had changes that were raised in the fiscal area from the emergence of a national entity with capacity to collect taxes. Be part of the hypothesis that the process of nationalization of resources

CÓMO CITAR: Ríos, E. (2019). Las oficinas de la aduana y resguardo del puerto de Rosario en tiempos de la Confederación Argentina, 1852-1854. America Latina en la Historia Económica, 26(1), e948. DOI: 10.18232/alhe.948 
and the transfer of these offices than led to numerous problems. This study pursues two objectives: on the one hand, observe the inner transformations of the mentioned offices of estate in its transition from the provincial sphere to the confederation and, on the other, analyze how this new situation affected the daily task activities of those who performed their work in these spaces. In this sense, it deepens in the tensions that originated in these dependencies at the time of managing different fiscal powers.

Key words: customs; finance; Rosario; Argentine Confederation.

JEL: N46; N96; H63.

Recibido: 11 de enero de 2018.

Aceptado: 20 de marzo de 2018.

Publicado: 4 de julio de 2018

Organismo colaborador: La presente investigación se desarrolló en el marco del proyecto State Building in Latin America dirigido por Juan Carlos Garavaglia y financiado por el European Research Council.

\section{INTRODUCGIÓN}

Celebrar esta unión de rentas, es lo que se llama nacionalizar sus contribuciones, crear un Tesoro Nacional; lo que vale decir, constituir un gobierno nacional, componer un Estado, formar una patria, en lugar de ser un grupo disperso e inconexo de pueblos sin nombre común, sin crédito exterior, sin figura respetable en la familia de las naciones (Alberdi, 1854).

La etapa de la Confederación Argentina (1852-1862) representó para las diferentes provincias que la conformaron profundos cambios políticos, económicos y sociales. Por más de tres décadas no había existido en el antiguo espacio rioplatense otra entidad estatal que no fuera la provincial 11 Estas asumieron todas las atribuciones que les correspondían como estados independientes: tenían sus monedas, cobraban impuestos, establecían aduanas, dictaban sus propias leyes y constituciones, aunque delegaron en Buenos Aires el manejo de las relaciones exteriores (Chiaramonte, 1997). Esta provincia logró una clara preponderancia mediante una política económica de exclusivismo comercial a través del cierre de los ríos interiores ${ }^{2}$ A inicios de 1850, algunos estados provinciales con Entre Ríos a la cabeza y apoyados desde el extranjero, se enfrentaron militarmente al ejército porteño con el objetivo de poner fin a esta situación que perjudicaba sus economías.

Con la derrota porteña, en la batalla de Caseros (1852), las provincias iniciaron el proceso de la conformación de un nuevo sistema político en clave nacional.$^{3}$ No obstante, como afirma J. Álvarez (1946): "Caseros fue un triunfo militar, no una fórmula jurídica concreta para estructurar la

\footnotetext{
${ }^{1}$ Luego de varios intentos constitucionales frustrados (1819 y 1826), el sistema político instituido recayó en las provincias convertidas en estados soberanos. La firma del Pacto Federal de 1831 otorgó la base para la creación de una confederación de Estados independientes que mantuvieron un mínimo de integración. La situación cambió con la conformación de la llamada Confederación Argentina, aunque en realidad se trató de un Estado federal más que confederal, tal y como se afirmó en la Constitución de 1853 (Chiaramonte, 1993).

${ }^{2}$ La aduana de Buenos Aires era una pieza clave de su economía. Allí se recaudaba 80 \% de los ingresos de la provincia (Halperín, 2005).

${ }^{3} \mathrm{La}$ complejidad de este proceso requiere de un examen que excede los límites de este trabajo, para ello, véase Scobie (1964).
} 
economía nacional sobre nuevas bases." La firma de un pacto en San Nicolás, cuyo eje central era la convocatoria al congreso constituyente, fue el primer paso hacia la integración. Entre las cláusulas incluidas en el tratado, algunas, como la nacionalización de las aduanas y la libre navegación de los ríos interiores, afectaban directamente los intereses económicos de Buenos Aires. Su negativa a ceder la aduana, entre otras razones esgrimidas, provocó la separación, entre 1852-1861, de Buenos Aires del resto de estados provinciales. La secesión porteña tuvo efectos disruptivos sobre la economía. Rosario se volvió la alternativa más fuerte para tomar el lugar de principal puerto exterior de la confederación logrando, en ese contexto, posicionarse también la ciudad.

El presente artículo centra su interés en las oficinas de aduana y resguardo del puerto de Rosario y busca analizar los cambios ocurridos en estos años. Rosario incidió como articulador del espacio económico-mercantil durante esta experiencia. La supresión de las aduanas interiores aceleró el tráfico comercial con las provincias del centro y norte. En el contexto de la confederación pasó de ser, en pocos años, un pequeño poblado de menos de 1000 habitantes a convertirse en una ciudad muy dinámica que habitaban más 9000 personas ${ }^{4}$ Las transformaciones en los ámbitos comercial y financiero permitieron su vinculación directa con los mercados extranjeros y la ampliación de su participación en los circuitos comerciales con las provincias interiores. Además, la reactivación económica propulsó la instalación de numerosos negocios, casas comerciales, entidades tanto financieras como bancarias y algunas industrias (Álvarez, 1943; Bonaudo, 2006; Frid, 2012; Gallo, 1965).

Esta investigación se propone contribuir al estudio de las transformaciones de la fiscalidad de las provincias con la emergencia de una nueva entidad con capacidad de cobrar impuestos 5 Los años que median entre 1852 y 1854 constituyen un momento bisagra en el proceso de transformación en las finanzas nacionales y provinciales en el que se requirió diferenciar de manera explícita el derecho a percibir tributos en dos niveles, confederal y provincial. ${ }^{6}$ La elaboración de una legislación fiscal común representó un paso importante del proceso de conformación del Estado central, pero su puesta en práctica conllevó un sinnúmero de problemas ya que no se contaba con una estructura administrativa cimentada que velara para que la misma fuese cumplida. La instalación de oficinas -donde centralizar los fondos enviados desde los diferentes puntos donde se realizaba la colecta-, el nombramiento de administradores de rentas nacionales -encargados de controlar los recursos que correspondían al Estado central- y la creación de una tesorería -encomendada a la tarea de examinar las cuentas y autorizar los pagos- eran medidas fundamentales, pero requerían de tiempo para que funcionaran de forma adecuada (Garavaglia, 2016). Entretanto, la recaudación de los aranceles nacionales quedó en manos de las administraciones provinciales de Hacienda.

La instauración de este nuevo sistema fiscal fue concomitante con el debate sobre el diseño institucional y administrativo. En oposición a un itinerario desarrollado desde diversas corrientes historiográficas que parten de la hipótesis de que la confederación fue un proyecto frustrado de nación 7 los estudios actuales han mostrado la importancia de estos años en la conformación de una dirigencia nacional como un proceso de articulación y retroalimentación desde la esfera provincial a la nacional (Bragoni y Míguez, 2010). Las elites políticas provinciales se integraron al

\footnotetext{
${ }^{4}$ Registro estadístico, en Carrasco (1900).

${ }^{5}$ Véanse Herrera (2010) y Rex (2004) sobre el caso tucumano; Schaller (2002) sobre Corrientes o Romano (1992) sobre Córdoba, quienes muestran que las medidas implementadas demoraron en demoler el viejo sistema fiscal.

${ }^{6}$ Sobre la construcción de una fiscalidad central en otras experiencias de federalismo, el caso mejor estudiado es sin duda el mexicano: Jáuregui (2010); Pantoja (2007); Marichal y Marino (2001); Sánchez, Jáuregui e Ibarra (2001).

${ }^{7}$ Para un balance historiográfico, véase Mega (2010).
} 
gobierno confederacional al tiempo que se crearon instituciones para canalizar los vínculos entre ambas esferas de poder, construyendo vínculos y articulando ámbitos de negociación. Las provincias no sólo aportaron recursos, sino también el personal que configuró la estructura estatal. Este representó un proceso mediante el cual los empleados de la administración de las diferentes provincias convergieron para transformarse en la nueva administración del Estado central ${ }^{8}$

El presente trabajo analiza las transformaciones de la administración de Santa Fe en el terreno fiscal en los años inaugurales de la Confederación Argentina, y profundiza en las tensiones que surgieron al momento de gestionar las diferentes potestades fiscales. Algunas de las preguntas que guían esta investigación son cómo se fue tejiendo la trama fiscal e institucional en este proceso de conformación de una nueva entidad con capacidad de cobrar impuestos y de qué manera la construcción de un Estado en clave nacional condicionó el accionar de los empleados de las oficinas de aduana y resguardo del puerto y modificó las prácticas cotidianas en el interior de estas dependencias.

Las dificultades para abordar este periodo son muchas. Las fuentes no sólo son escasas, además se hallan fragmentadas en diversos legajos de los libros del fondo de Contaduría del Archivo General de la Provincia de Santa Fe (en adelante AGSF). La provincia contaba entonces con dos aduanas, ubicadas en la ciudad capital y en Rosario respectivamente. Sobre la primera casi no se conservan documentos, sólo algunos expedientes sueltos que no permiten un análisis completo sobre su funcionamiento. Más abundante es la información sobre la de Rosario, aunque los datos se hallan dispersos -lo que dificulta la reconstrucción de sus movimientos- es posible confeccionar un cuadro de los movimientos de esta caja receptora entre octubre de 1852 y julio de 1854 . Una sustanciosa fuente de información la aportan las notas que circulaban entre los empleados de las oficinas de aduana y resguardo de Rosario con la colecturía general de la provincia. Brindan información de primera mano sobre las vivencias más cotidianas que se sucedían en el interior de estos espacios. Era el medio por el cual los empleados elevaban sus quejas, descargan sus frustraciones y expresaban sus dificultades. A partir de 1855, la Confederación asumió el control de estas oficinas, por lo que las referencias a las aduanas desaparecen de los archivos provinciales.

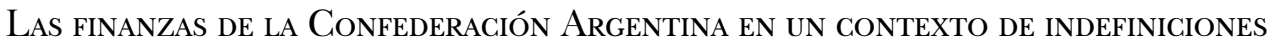

La conformación del tesoro nacional que permitiese a las autoridades del gobierno central hacer frente a sus obligaciones financieras - como eran el pago de sueldos civiles y militares, los empréstitos tomados para solventar la campaña militar contra Juan M. Rosas, la deuda y los gastos ordinarios que ocasionaron la instalación del gobierno- requería de inyecciones rápidas de dinero. La fiscalidad de la Confederación Argentina se estructuró en torno a los gravámenes al comercio 9 En el contexto latinoamericano no representaba una excepción, sino una regla. Un estudio comparativo sobre las finanzas de diferentes países ha mostrado que los impuestos al comercio exterior y los estancos fueron los dos principales componentes de los ingresos estatales durante el siglo XIX (Garavaglia, 2010a). La decisión además presentaba dos ventajas, para un gobierno en formación

\footnotetext{
${ }^{8}$ Véanse Ayrolo, Lanteri y Morea (2011), Lanteri (2013a, 2013b), Buchbinder (2004).

${ }^{9} \mathrm{Si}$ observamos algunos datos sobre los ingresos efectivos a las arcas de la Confederación entre 1853 y 1860 encontramos que poco más de $94 \%$ correspondía a rentas de aduanas (76.9\% era ingresos a las importaciones y 14.9 por exportaciones). Además, para $186092 \%$ de los ingresos de las aduanas confederadas provenía de las receptorías del Litoral, es decir Santa Fe, Entre Ríos y Corrientes. Sólo en la aduana de Rosario se recaudaba 44.9 \% de los ingresos totales convirtiéndose en el puerto más importante después del de Buenos Aires (Garavaglia, 2010b, p. 227).
} 
que aún no contaba con una administración central, le permitía utilizar las estructuras previas establecidas por los estados provinciales. Además, se pensaba que su percepción, al contrario de las contribuciones directas, casi no provocaba resistencias.

Es la más fácil, porque es imperceptible al contribuyente su pago, que casi siempre hace en el precio que da por los objetos que consume. Paga la contribución en el precio con que compra un placer y naturalmente la paga sin el disgusto que acompaña a toda erogación aislada. Esta calidad de la contribución indirecta es de mucho peso en países y en tiempos en que la autoridad empieza a establecerse, y necesita economizar los pretextos de descontento y de inobediencia (Alberdi, 1854).

El primer paso hacia la conformación de una fiscalidad central lo representó la firma del Acuerdo de San Nicolás (1852) que estableció la libertad de tránsito en el comercio entre las provincias. En el mismo se asentó la necesidad de reglamentar la navegación de los ríos interiores, de procurar la seguridad del territorio y nacionalizar las rentas fiscales. Entretanto "las provincias concurrirán proporcionalmente con el producto de sus aduanas exteriores [sic], hasta la instalación de las autoridades constitucionales, a quienes exclusivamente competirá el establecimiento permanente de los impuestos nacionales" 10 Estas enfrentaron entonces el desafío de hallar nuevas fuentes de recursos 11 Las autoridades de Buenos Aires además de entregar los recursos de aduanas debían dejar bajo el control del gobierno de la Confederación las oficinas de aduana y resguardo del puerto convertidas en sede de la administración central de Hacienda $\sqrt{12}$ Se puso en marcha en estas dependencias un proceso de recambio de su personal ubicando en puestos clave a personas de confianza del mismo Urquiza ${ }^{13}$ Las medidas provocaron un fuerte rechazo por parte de los representantes de legislatura porteña, que se negaron a firmar el acuerdo y a entregar el control de la aduana. Cabe mencionar que "la aduana es la clave de todo el misterio y, por lo tanto, el control de puerto es entonces la llave que abre el dominio de Buenos Aires sobre sus provincias hermanas" (Garavaglia, 2005). El descontento eclosionó en el levantamiento del 11 de septiembre de ese año. Las autoridades de Buenos Aires desconocieron a Urquiza como director provisorio y rompieron relaciones con la Confederación ${ }^{14}$ La decisión frenó la aplicación de muchas de las reformas con-

\footnotetext{
${ }^{10}$ Registro Oficial de la República Argentina que comprende los documentos expedidos desde 1810 hasta 1873 (en adelante RORA) (1879), pp. 14-15.

${ }^{11}$ En los últimos años, los estudios se han focalizado en la situación particular de las finanzas de las distintas provincias. Desde una perspectiva fiscal se ha puesto el acento en la forma que lograron financiarse y sostener su administración. Un examen de sus fundamentos económicos, su estructura social y sus vaivenes políticos obligaron a la elaboración de cronologías más ajustadas a cada caso. Un balance historiográfico en Ríos (2017).

${ }^{12}$ Reglamento de aduanas (1852) donde se contemplaba la creación de una oficina denominada Inspección General de Aduanas Nacionales -que debía ser integrada por un inspector general, un jefe de departamento y cuatro visitadoresque tendría como sede a la aduana de Buenos Aires de la que dependerían todas las aduanas nacionales. RORA (1879), pp. 37-42.

${ }^{13}$ Se nombró a Elías Bedoya como visitador de las aduanas nacionales, al consejero de Estado Francisco Pico como inspector de las aduanas exteriores y a Benjamín Gorostiaga como asesor de gobierno y auditor general de Guerra y Marina. RORA (1879), p. 48.

${ }^{14}$ El ministro de Gobierno de la provincia M. Leiva anunciaba al receptor de Rosario y administrador de la aduana: "no haga innovación alguna hasta segunda orden en la administración a su cargo y que se guarde el mismo sistema de rentas". Notas de ministros Manuel Leiva, al receptor del Rosario, don Francisco Carbonell que tratan sobre la instalación de la aduana Nacional en el Rosario en septiembre de 1852. Contaduría, t. 90, leg. 14, en Archivo General de la Provincia de Santa Fe (en adelante AGSF).
} 
signadas y cimentó las bases para la construcción de dos Estados independientes -el de Buenos Aires y la Confederación Argentina- que permanecieron separados por espacio de casi diez años (Scobie, 1964).

El gobierno de la Confederación invirtió ingentes esfuerzos en construir una administración centralizada con sede en la ciudad de Paraná. En lo que respecta al plano económico-fiscal, se promulgó el Reglamento para la Navegación de los Ríos Paraná y Uruguay y las Aduanas Nacionales ${ }^{15}$ que contenía una serie de medidas en pos de organizar los recursos fiscales ${ }^{16}$ Para las provincias litorales los ríos eran las principales arterias de comunicación y una pieza central en el entretejido de los vínculos comerciales. Al hallarse rodeadas de agua que podían surcar buques de ultramar, sus puertos podían convertirse en marítimos intensificando sus contactos con los mercados extranjeros (Gschwind, 1927). La aduana de Rosario se transformó entonces en la principal de la Confederación convirtiendo a su puerto en uno de los ejes fundamentales dentro de los circuitos económicos y financieros de la Confederación (Ensinck, 1971). Estaba preparado para recibir embarcaciones debido a que la profundidad del agua permitía la llegada de buques de gran calado. Además, la cercanía con el puerto de Buenos Aires y las facilidades en la comunicación fueron algunas de las razones que se sopesaron al tomar la decisión. 17

Las administraciones provinciales retuvieron el control de las oficinas de aduanas, aunque con cambios; los empleados de Hacienda estuvieron obligados a llevar una contabilidad doble en la que se diferenciaban en dos columnas los ingresos y los egresos provinciales de los nacionales. Entretanto se fijaban las tarifas que imperarían a nivel nacional, cobraron los derechos según sus leyes fiscales preexistentes más $7 \%$ adicional sobre los avalúos de los efectos introducidos en las provincias litorales y $5 \%$ sobre el tránsito nacional. Las mercancías de procedencia o producción extranjera, y los productos de fabricación o industria de Buenos Aires, introducidos por tierra a cualquiera de las provincias del interior, debían abonar sus tasas en la aduana de Rosario. También se pagarían allí los aranceles de exportación correspondientes a los efectos que de las provincias interiores enviasen a Buenos Aires 18

Para 1853, en la aduana de Rosario se recaudaron 70000 pesos fuertes correspondientes al fondo nacional -una suma formada por el cobro de $7 \%$ sobre introducción nacional y $5 \%$ sobre derecho de tránsito- y 67000 pesos como fondo provincial entre alcabala (más de $30 \%$ ), derechos provinciales cobrados en el puerto (20\%) e impuestos de aduana (14\%) (véase cuadro 1$)$. Los datos permiten observar que el traspaso de las entradas de aduanas a jurisdicción nacional no significó la

\footnotetext{
15 RORA (1879), pp. 48-49.

${ }^{16} \mathrm{El} 3$ de octubre de 1852 se establecieron trece aduanas sobre el río Paraná y cinco sobre río Uruguay. Los puertos de entrada de la Confederación fueron divididos en tres clases. Los de primera, sobre el río Paraná, eran los ubicados en Rosario, Santa Fe, Paraná y Corrientes. Fueron considerados puertos de segunda clase Gualeguay, Victoria y Goya. Mientras que los de Diamante, la Paz, Bella Vista, Empedrado, Itati e Ita-ibate se les otorgó el tercer rango. Sobre el río Uruguay no se establecieron puertos de primera; sólo de segunda: Gualeguaychu, Concepción del Uruguay, Concordia y la Restauración; y de tercera: Federación, La Cruz y Santo Tomé. También se instaló una línea de aduanas en los Andes, para poner bajo control el comercio con Chile y Bolivia. Estas oficinas se instituyeron bajo el nombre de puertos secos entradas por tierra. Reglamentando la navegación de los ríos Paraná y Uruguay, y las aduanas nacionales. RoRA (1879), pp. 48-49.

${ }^{17}$ Carta de Frank Parrish, vicecónsul de Buenos, 30 de septiembre de 1853. Public Record Office, Foreing Office, Commercial and Consular Correspondence, 118, t. 75, fs. 262-266, National Archives (NA).

${ }^{18}$ Reglamento para la navegación de los ríos Paraná y Uruguay y las aduanas nacionales. RORA (1879), pp. 48-49.
} 
MAPA 1. UBICACIÓN DEL PUERTO DEL ROSARIO

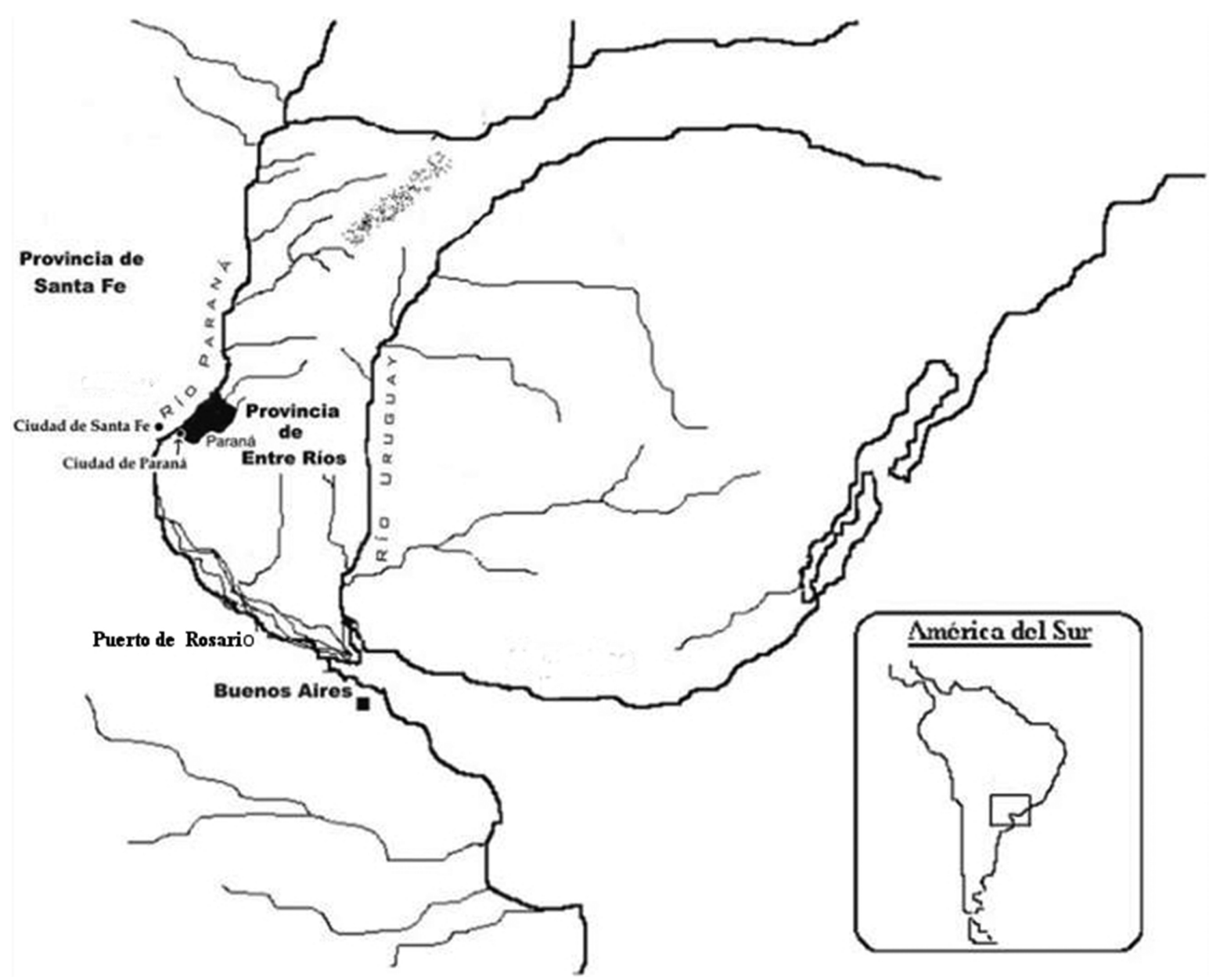

Fuente: Djenderedjian y Martirén (2012).

supresión definitiva de los derechos provinciales 19 Las autoridades locales continuaron -mientras retuvieron bajo su control la gestión de dichas oficinas- percibiendo gravámenes al comercio, tal como lo permitía el Reglamento de Aduanas nacionales (1852). Se cobraban derechos de eslingaje, anclaje, salidas, guías, entre otros.

Se utilizaron también planillas de doble carga para separar los gastos nacionales de los provinciales. Una porción muy significativa de los egresos - más de $35 \%$ de los mismos- estaba dirigida a cubrir gastos militares ${ }^{20}$ La Confederación asumía el control de las fronteras con los indios, por

${ }^{19}$ Es preciso considerar que los impuestos indirectos constituían los principales ingresos de Santa Fe. Entre las décadas de 1820 y 1850 los derechos de importación y de exportación constituyeron las principales fuentes de financiamiento, aunque los primeros ocuparon un lugar más significativo, al tiempo que las entradas y las salidas marítimas tuvieron más peso que las terrestres. Véase Chiaramonte, Cussianovich y Tedeschi (1993).

${ }^{20}$ Los teóricos del fiscal-military state han señalado que los primeros pasos de la construcción estatal requerían de la instauración del monopolio de la fuerza hacia afuera y hacia adentro del espacio sobre el cual este reivindicaba su control. Estos autores argumentan que conjuntamente con el incremento de los gastos bélicos y de represión era indispensable 


\section{CUADRO 1. CUENTA INGRESOS DE LA RECEPTORÍA Y ADUANA DE ROSARIO, 1853 (EN PESOS FUERTES)}

\begin{tabular}{lcc}
\hline Ingresos & Nacionales & Provinciales \\
\hline $7 \%$ por introducción nacional & 21343 & - \\
$5 \%$ sobre el derecho de tránsito nacional & 49298 & - \\
Aduana provincial & - & 9852 \\
Alcabala & - & 21840 \\
Derechos provinciales cobrados en el puertoa & - & 14026 \\
Piso de carretas & - & 1056 \\
Papel sellado & - & 4442 \\
Patentes (marítimas y terrestres) & - & 3733 \\
Producto del remate de cueros & - & 2582 \\
Reintegro de la Confederación a la provincia por gastos nacionales & - & 5792 \\
Corrales & - & 2117 \\
Otros ingresos & - & 1662 \\
Total & 70641 & 67102 \\
\hline
\end{tabular}

${ }^{a}$ Corresponden a los derechos de eslingaje, anclaje, salidas y guías.

Fuente: elaboración propia con base en Contaduría, t. 98, legs. 6, 7, 9 y 10, en AGSF.

lo cual se dedicaron algunos recursos para la organización de líneas defensivas, el establecimiento de fortines y la designación de autoridades en estas zonas. No obstante, la mayor parte de estas partidas fue cubierta con recursos provinciales. El 1 de septiembre de 1853 el administrador de Rosario envía una nota al colector general de la provincia, José Antonio Lassaga, informando que las cuentas podían "contener equivocaciones", debido a que ante cualquier duda sobre a cuál fondo pertenecían las partidas militares -a saber, consumos de reses, caballos o pertrechos- se consignaban siempre como gastos provinciales. Para intentar remediar esta situación, que comprometía seriamente los intereses del tesoro provincial, solicitó una revisión de los legajos y los documentos que permitiera discriminar los gastos de forma adecuada. La medida de poco sirvió. Hasta 1855 cuando se nacionalizaron las fuerzas militares provinciales, las provincias se ocuparon de cubrir gastos de defensa contra los indios, pagar una parte de los sueldos de las tropas y surtir de raciones

el desarrollo de un sistema burocrático de percepción de rentas. Se establecía entonces una conexión entre esfuerzo guerrero, extracción fiscal y crecimiento de la burocracia. La historiografía europea tiene una larga tradición de trabajos que versan sobre el modelo de fiscal-military state: Brewer (1994); Collins (1997); Brien y Hunt (1993); Tilly (1990); Storrs (2009). No obstante, nuevas miradas han matizado esta vinculación mecánica guerra-fiscalidad-construcción del estado. La guerra ha sido estudiada como el marco en el que se produjo la construcción de los Estados y, como tal, condicionó ese proceso. En estas nuevas indagaciones, lejos de responder a un modelo lineal de racionalización parece postularse que los Estados del siglo xix nacieron y se desarrollaron en un contexto de contingencia cuyo determinante mayor era la guerra y su núcleo central las fuerzas militares. Para un análisis de esta cuestión, véase Garavaglia, Pro Ruiz y Zimmermann (2012). 


\section{CUADRO 2. EGRESOS DE LOS FONDOS NACIONAL Y PROVINCIAL EN LA RECEPTORÍA Y ADUANA DE ROSARIO, 1853 (EN PESOS FUERTES)}

\begin{tabular}{lcccc}
\hline Egresos & Nacional & Porcentaje & Provincial & Porcentaje \\
\hline Gastos militares & 23515 & 35.8 & 42738 & 54 \\
Comisión al expendedor de papel sellado & - & - & 206 & 0.2 \\
Sueldos empleados civiles & - & - & 4148 & 5.2 \\
Costo de postas & - & - & 1816 & 2.2 \\
Gastos guardia de Melincué & - & - & 1898 & 2.3 \\
Gastos estancia del Estado & - & - & 1660 & 2 \\
Gastos de la Comandancia de Rosario & - & - & 927 & 1.1 \\
Sueldos y gastos de la receptoría y resguardo & 1690 & 2.5 & 7139 & 9 \\
Instrucción primaria & - & - & 610 & 0.7 \\
Empréstitos & - & - & 1179 & 1.49 \\
Dinero abonado por orden del gobierno de la provincia & - & - & 4608 & 5.82 \\
Justicia & - & - & 591 & 0.7 \\
Gastos en indios & 1107 & 1.6 & 400 & 0.5 \\
Varios gastos & 1489 & 2.2 & 5839 & 7.3 \\
Obras públicas & - & - & 769 & 0.9 \\
Gastos de correos & 204 & 0.3 & - & - \\
Traslado de fondos a la Tesorería General & 30794 & 46.9 & - & - \\
Gastos hechos en el Congreso y & 2069 & 3.1 & - & - \\
preparativos para la sanción de la & & & & \\
Constitución & & & & \\
Total & 65588 & 100 & 79114 & 100 \\
\hline
\end{tabular}

Fuente: elaboración propia con base en Contaduría, t. 98, legs. 1, 6, 7, 9, 10, en AGSF.

a la guarnición. 21 Afrontar estos pagos representó un golpe duro a sus finanzas provinciales, de por sí muy precarias, tan es así que en la receptoría de Rosario concluyó el año con un déficit de más de 12000 pesos.

La Confederación se había comprometido a pagar la mitad de los sueldos del personal de Hacienda y a nacionalizar la deuda provincial anterior a 1852. Sin embargo, para cubrir las partidas de sueldos sólo se destinaron poco más de 1600 pesos, apenas un cuarto de los gastos de la administración en Rosario (véase cuadro 2). El resto de los sueldos se cubrió con fondos provinciales. Este año no se destinaron partidas por concepto de deuda provincial.

Casi la mitad de los egresos correspondió al traslado de gastos desde la aduana y receptoría de Rosario hacia la tesorería general. Este dinero servía para cubrir gastos de carácter nacional que se libraban en otras cajas que carecía de los fondos necesarios. Aun cuando se contaba con una partida específica -Gastos del Congreso Constituyente-, un análisis minucioso de los libramientos muestra que estas partidas se utilizaron para cubrir los gastos en los preparativos del Congreso celebrado en la ciudad de Santa Fe durante varios meses de 1853, el acondicionamiento de la sala y el traslado de los congresistas desde diferentes provincias, así como la entrega de un estipendio como compensación por la tarea. Esta dualidad en las cuentas generó confusión en el propio adminis-

\footnotetext{
${ }^{21}$ Leyes y decretos, ceses y nombramientos y varias notas del ministro dirigida al colector general José A. Lassaga de todo el año 1853. Contaduría, t. 98, leg. 20, en AGSF.
} 
trador de aduanas de Rosario, Usladislao Frías, quien preguntaba por ello al colector: "el traslado de fondos a la contaduría general para gastos nacionales, como pago del Congreso por ejemplo las daré como invertidas en este soberano cuerpo o sólo expresaré que se han trasladado a la contaduría general para gastos nacionales, como dicen la mayor parte de las órdenes del gobierno" ${ }^{22}$ Pese al desconcierto, se resolvió mantener la denominación de "traslado" y que la contaduría destinara el dinero a cubrir los gastos que el gobierno nacional estimara más urgentes. 23

\section{LOS CAMBIOS EN LA ADMINISTRACIÓN DE HACIENDA EN 1854}

La sanción por parte del Congreso Constituyente del Estatuto para la Organización de la Hacienda y el Crédito Público - un proyecto elaborado por Mariano Fragueiro- debía poner fin a estas tensiones y reglamentar las finanzas de la Confederación. En el mismo se decretaba la creación de la Administración General de Hacienda y Crédito con sede en la ciudad de Paraná donde debían reunirse todos los fondos del tesoro nacional, remitidos por las diferentes sucursales erigidas a lo largo de todo el territorio. La administración tenía entre sus muchas atribuciones que encargarse de la inspección y gestión de todas las restantes dependencias fiscales -obligadas a remitir allí las planillas de ingresos y egresos-, de autorizar los libramientos para el pago tanto de sueldos como de diversos gastos y de inspeccionar la compra y venta de muebles e inmuebles. Se ocupaba también del registro y clasificación de la deuda nacional (interna y externa) e intervenía en toda operación de crédito público ${ }^{24}$

El estatuto contemplaba la formación de un banco nacional, donde la administración general se reuniría en cuerpo, y de una casa de moneda. Este banco fue transformado entonces en contaduría y tesorería nacional. La Confederación abriría una cuenta corriente donde las entradas de fondos nacionales ingresaran mediante depósitos fiscales. Desde allí se abonarían los libramientos autorizados por el gobierno, según lo estipulado por el presupuesto general de gastos que regía cada año. Las medidas se acompañaron de una importante reforma monetaria. El gobierno de la Confederación comenzó a emitir papel moneda como una manera de contar con liquidez fiscal inmediata para cubrir los gastos estatales 25

A inicios de 1854, la administración general del banco comenzó a ser instalada prácticamente sin ningún tipo de preparación. Junto con la oficina central de Paraná, en la provincia de Santa Fe se establecieron dos dependencias, una en Rosario y la otra en Santa Fe. Las aduanas y los resguardos del puerto quedaron entonces bajo la inspección del Banco Nacional. ${ }^{26}$ Su designación como Oficina de Contaduría y Tesorería Nacional en Rosario no representó una escisión entre fondos nacionales y provinciales. Aunque la disposición no separó ambas esferas fiscales, el ministro de Hacienda, Mariano Fragueiro, solicitó al gobierno provincial autorizar que el administrador

\footnotetext{
${ }^{22}$ Correspondencia del interventor Gabriel López, y administrador de aduana de Rosario d. Uladislao Frías, dirigida al contador general José Antonio Lassaga. Contaduría, t. 94, leg. 24, en AGsF.

${ }^{23}$ Correspondencia del interventor d. Domingo Crespo y del ministro Manuel Leiva dirigida al receptor de Hacienda Francisco Carbonell. Contaduría, t. 94, leg. 22, en AGSF.

24 RORA (1879), pp. 82-91.

${ }^{25}$ Las distintas provincias rioplatenses habían tenido o tenían experiencia en la utilización de este tipo de divisas en algunos casos pasajera como la de Santa Fe o Córdoba. En otros casos, el uso del papel moneda modificó las prácticas monetarias desalojando de la circulación a la plata y al oro. Los estudios realizados sobre las provincias de Buenos Aires y Corrientes se constituyen en los ejemplos más sonantes. Véanse Álvarez (1929), Irigoin (2003), Schaller (2001), Nicolini y Parolo (2009).

${ }^{26}$ Organizando la administración de Hacienda y Crédito público, conforme al estatuto de 1853. RORA (1879), p. 94.
} 
de aduana y receptor provincial de Rosario, Uladislao Frías - mientras ostentara ambos puestosconsignase la recaudación perteneciente a Santa Fe en la tesorería nacional en calidad de depósito ${ }^{27}$ Con esta medida se pretendía centralizar en esa dependencia los ingresos de la aduana y conseguir así que las autoridades nacionales tomaran en sus manos el manejo de sus fondos sin la intermediación de las autoridades provinciales.

El estatuto para la organización de la Hacienda establecía que, desde el 1 de enero de 1854, la centralización de los recursos debía ser completa. Sin embargo, al no contar con una estructura administrativa acorde con las exigencias de la tarea, las aduanas permanecieron en manos de las provincias. ${ }^{28}$ Las cuentas para el primer semestre de 1854 continuaron siendo de doble entrada (véase cuadro 3). Bajo el rubro entradas nacionales encontramos que la situación de los ramos se invirtió: lo recaudado por tránsito nacional que representaba más de $70 \%$ de los ingresos se redujo a $18 \%$, mientras por lo recaudado por introducción de mercancías pasó de 27 a $80 \%$ de los ingresos, es decir que el peso de la fiscalidad se trasladó a los consumidores y no en los productores que exportaban sus producciones. En este semestre, los ingresos provinciales aumentaron, mientras que los balances de 1853 estimaban la recaudación en aproximadamente 67000 pesos, sólo el primer semestre de 1854 ingresó la cantidad de 62000 pesos. La mitad de los ingresos provenían de los derechos de aduana, que, a partir de 1855, dejaron de recaudarse. Las entradas eventuales representaron $12 \%$ de los ingresos. Entre los eventuales se percibieron 4000 pesos de la Confederación correspondiente a los subsidios que el gobierno había acordado con la provincia, como retribución a la nacionalización de la aduana. El resto de los ingresos eran patentes (7.8\%), alcabala (3.4\%), papel sellado (1.4\%), remate de corrales (1.6\%), entre otros.

Es posible notar que más de $60 \%$ de los gastos nacionales corresponde a partidas militares (armamentos, vestuario, sueldos, ranchos, etc.) y poco más de $20 \%$ de los egresos del fondo nacional para pagar sueldos de empleados civiles - personal de la contaduría general, de la aduana y resguardo del puerto- y el alquiler de almacenes, así que es posible notar gastos destinados a cubrir la deuda de Santa Fe anterior a 1852 (véase cuadro 4). Aunque efímera en sus montos, representaba un paso en el acatamiento a los acuerdos firmados en San Nicolás. La fiscalidad provincial se vio notoriamente aliviada reduciendo sus gastos a casi un tercio -pasó de 42000 a 12800 pesos-, aunque los gastos militares continuaron representando más de $45 \%$ de los egresos provinciales, desaparecieron algunas partidas como las destinadas a la defensa contra los indios.

Ahora bien, las autoridades santafesinas desconocían a cuánto ascendía el monto de la deuda anterior a 1852, pues la inestabilidad política había tenido su correlato en la marcha de la administración de Hacienda dejando sumida la fiscalidad provincial en un verdadero caos. Recién a mediados de 1853, por solicitud del gobierno central se comenzó a recabar información para conocer cuáles eran los montos de la deuda y a confeccionar las planillas de deudores del fisco (véase cuadro 5).

Según el informe Usladislao Frías, administrador de la aduana nacional, la deuda reclamada en la receptoría de Rosario alcanzaba la cantidad de 25092 pesos, apenas $2.5 \%$ correspondía a sueldos de personal civil y casi $37 \%$ era sueldos militares. La mayor parte era deuda contraída con hacendados y estancieros. Se trataba de suministros de reses - voluntarios y forzosos- que entregaron para surtir a las tropas en diferentes enfrentamientos militares, en otras palabras, eran

\footnotetext{
${ }^{27}$ Notas del administrador de aduana de Rosario, al contador General de la provincia. Contaduría, t. 97, leg. 5, en AGSF.

${ }^{28}$ Leyes y decretos, ceses y nombramientos comunicados por intermedio de la secretaria de gobierno al colector d. Cayetano Echagüe. Contaduría, t. 98, leg. 60, en AGSF.
} 


\section{CUADRO 3. INGRESOS DE FONDOS NAGIONAL Y PROVINGIAL EN LA ADUANA DE ROSARIO, PRIMER SEMESTRE DE 1854 (EN PESOS FUERTES)}

\begin{tabular}{|c|c|c|c|c|c|}
\hline Ingresos fondo nacional & Pesos fuertes & Porcentaje & Ingresos fondo provincial & Pesos fuertes & Porcentaje \\
\hline $\begin{array}{l}5 \% \text { de tránsito para el interior } \\
\text { de la provincia }\end{array}$ & 6766 & 18.8 & Patentes & 4907 & 7.8 \\
\hline $\begin{array}{l}7 \% \text { de introducción de la pro- } \\
\text { vincia }\end{array}$ & 29072 & 81.2 & Papel sellado & 957 & 1.4 \\
\hline- & - & - & $\begin{array}{l}\text { Derechos de } \\
\text { aduana y puerto } \\
\text { que cobraba la } \\
\text { provincia }\end{array}$ & 41528 & 66.5 \\
\hline- & - & - & Piso de carretas y arrias & 418 & 0.66 \\
\hline- & - & - & Derechos municipales & 423 & 0.67 \\
\hline- & - & - & Remate de corrales & 1013 & 1.63 \\
\hline- & - & - & $\begin{array}{l}\text { Entradas eventua- } \\
\text { les incluso los } 4 \\
000 \text { recibidos del } \\
\text { banco }\end{array}$ & 7456 & 12 \\
\hline- & - & - & Préstamos & 2400 & 3.85 \\
\hline- & - & - & Alcabala & 1899 & 3.04 \\
\hline- & - & - & Otros & 109 & 0.17 \\
\hline Total & 35839 & 100 & Total & 62444 & 100 \\
\hline
\end{tabular}

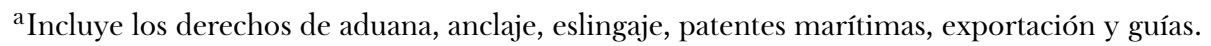

Fuente: elaboración propia con base en Contaduría, t. 98, legs. 31, 33-34, en AGSF. 


\section{CUADRO 4. EGRESOS DE LOS FONDOS NACIONAL Y PROVINCIAL EN LA ADUANA DE ROSARIO, PRIMER SEMESTRE DE 1854 (EN PESOS FUERTES)}

\begin{tabular}{|c|c|c|c|c|c|}
\hline Egresos fondo nacional & Pesos fuertes & Porcentaje & Egresos fondo provincial & Pesos fuertes & Porcentaje \\
\hline Alquiler de almacenes & 1329 & 1.98 & Alquiler de almacenes & 362 & 1.3 \\
\hline $\begin{array}{l}\text { Empleados de } \\
\text { aduana y resguar- } \\
\text { do, médico del } \\
\text { hospital }\end{array}$ & 398 & 0.60 & Empleados de aduana y resguardo & 452 & 1.62 \\
\hline Maestros de postas & 599 & 0.89 & Por sueldos y gastos en las estancias & 422 & 1.51 \\
\hline $\begin{array}{l}\text { Deuda de la pro- } \\
\text { vincia anterior a } \\
1852\end{array}$ & 1450 & 2.16 & Juzgado de paz & 293 & 1.05 \\
\hline $\begin{array}{l}\text { Contaduría gene- } \\
\text { ral mitad de los } \\
\text { sueldos para gastos } \\
\text { nacionales }\end{array}$ & 11345 & 16.9 & Sueldos civiles & 592 & 2.12 \\
\hline Descuento en letras & 309 & 0.46 & Descuento en letras & 50 & 0.17 \\
\hline Gastos en indios & 895 & 1.33 & Obras públicas & 1237 & 4.44 \\
\hline Administración de correos & 560 & 0.83 & Expendedor del papel sellado & 43 & 0.15 \\
\hline Devolución de derechos & 306 & 0.45 & Préstamos & 2400 & 8.61 \\
\hline $\begin{array}{l}\text { Gastos milita- } \\
\text { res, compras en } \\
\text { vestuario, ar- } \\
\text { mamentos, } 100 \\
\text { mantas, sueldos } \\
\text { y satisfacción de } \\
\text { jefes y oficiales, } \\
\text { igualmente el } \\
\text { pago del auxi- } \\
\text { lio del Ejército } \\
\text { Libertador }\end{array}$ & 44657 & 66.6 & $\begin{array}{l}\text { Gastos militares } \\
\text { incluso vestua- } \\
\text { rios, armamentos, } \\
\text { gratificaciones y } \\
\text { sueldos }\end{array}$ & 12800 & 45.9 \\
\hline Diversos gastos & 4548 & 6.8 & Diversos gastos & 8631 & 30.9 \\
\hline - & - & & Policía & 307 & 1.10 \\
\hline Total & 66996 & 100 & Total & 27859 & 100 \\
\hline
\end{tabular}

Fuente: elaboración propia con base en Contaduría, t. 98, legs. 31, 33, 34, en AGSF.

gastos militares. Es necesario considerar que este primer informe estaba lejos de reflejar la verdadera cara del endeudamiento. La poca precisión en los datos recabados y las quejas de numerosos acreedores pervivían todavía en los años sesenta 29

La deuda de la nación con la provincia se acrecentó fuertemente a lo largo de estos años. Entre diciembre de 1853 y julio de 1854 prácticamente se duplicó. El contador general de la provincia, Cayetano Echagüe, manifestaba al ministro de Hacienda de la Confederación que las sumas adeudadas alcanzaban la cantidad de 76984 pesos (véase cuadro 6). El incremento no era consecuencia de nuevos informes, sino que se trataba de deuda acumulada correspondiente a

${ }^{29} \mathrm{El} 20$ de enero de 1863 las autoridades provinciales realizaron un llamado a todos aquellos que tuvieran créditos contra el Estado por servicios anteriores al 1 de mayo de 1853 a que presentaran sus reclamaciones. Aunque se trataba de una deuda que, según el decreto del Congreso Nacional Constituyente del 9 de diciembre de 1853, correspondía a la nación desde el gobierno provincial se consideraba necesario dar respuesta a estos acreedores (Registro Oficial de la Provincia de Santa Fe, 1890, t. 4, p. 333). 


\section{GUADRO 5. DEUDA DE LA PROVINGIA DE SANTA FE CONSIGNADA EN LA RECEPTORÍA DE ROSARIO, ANTERIOR A 1852 (EN PESOS FUERTES)}

\begin{tabular}{lc}
\hline Rubros & Montos \\
\hline Sueldos militares & 9363 \\
Sueldos civiles & 640 \\
Auxilio de reses & 14375 \\
Maestro de postas & 444 \\
Total & 25092 \\
\hline
\end{tabular}

Fuente: elaboración propia con base en Contaduría, t. 98, leg. 28, en AGSF.

gastos nacionales que la provincia había cubierto con fondos propios ${ }^{30} \mathrm{Si}$ observamos las cifras totales de ingresos y egresos de fondos nacionales en Santa Fe, la Confederación recaudó 118633 pesos y gastó 197781 pesos, teniendo un saldo negativo de 79148 pesos. La transferencia de recursos de la provincia a la nación, mediante el pago de algunos gastos nacionales, fue un modo de frenar el déficit que presentaban las finanzas del Estado central en estos años.

\section{Padecimientos cotidianos de los empleados de la aduana}

La nacionalización de la aduana no significó un recambio del personal de estas oficinas. Las autoridades del gobierno central decidieron mantener a los empleados nombrados por la provincia argumentando que "confiaba que estos contarían con méritos suficientes para cumplir con los servicios requeridos" ${ }^{31}$ El complejo entramado fiscal que se tejió entre la Confederación y las provincias -que obligó a llevar una contabilidad doble- provocó más de un dolor de cabeza para los empleados de las dependencias de Hacienda. Tal como lo retratan las palabras que el administrador de la aduana y receptoría de Rosario, Francisco Carbonell, dirigía al colector general de la provincia:

[...] es preciso señor que usted conteste [...], pues yo no puedo menos que continuamente molestarlo, nada menos que hoy con el nuevo arreglo me hallo en el caso de varias notas para sentar en las partidas en el libro manual como en el público o acaso será preciso usar libro por separarse para deducir el $7 \%$ que pertenece como nacional, como asimismo el $5 \%$ del tránsito: yo deseo que su bondad se digne mandarme un diseño para poderme expedir pues de otro modo no podré arribar con el acuerdo que deseo 32

\footnotetext{
${ }^{30}$ Nota del contador general Cayetano Echagüe elevando los estados de la deuda nacional al Ministerio, quedando en diciembre 31 de 1853, 371173 pesos fuertes con $23 / 4$ reales por saldo a favor de la provincia y en julio 31 de 1854 , 76984 pesos fuertes. Contaduría, t. 98, leg. 22, en AGSF.

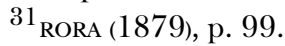

${ }^{32}$ Correspondencia del receptor de Rosario Carbonell dirigida al contador general José Lassaga en todo el año 1852 (Rosario, 29 de octubre de 1852). Contaduría, t. 90, leg. 6, en AGSF.
} 
CUADRO 6. DEUDA DE LA NACIÓN CON LA PROVINCIA CONSIGNADA EN LA RECEPTORÍA DE ROSARIO, 1853-1854 (EN PESOS FUERTES)

\begin{tabular}{lcc}
\hline Deuda & Diciembre de 1853 & Julio de 1854 \\
\hline Manifiesto precedente & 6690 & - \\
Deuda de la nación con la provincia & 37173 & 76984 \\
Letras a cobrar en Rosario & - & 3483 \\
Existencia en caja & 543 & 550 \\
Total & 44406 & 81017 \\
\hline
\end{tabular}

Fuente: elaboración propia con base en Contaduría, t. 98, leg. 22, en AGSF.

Llevar las contabilidades provincial y nacional complicó la tarea de los empleados de Hacienda. Así en septiembre de 1853 el receptor del departamento Rosario presentó su renuncia argumentando no tener la capacidad para dirigir ambas dependencias. ${ }^{33}$ La doble calidad de receptor de la provincia y administrador de la aduana nacional comportaba serios inconvenientes como el que surgió en torno a la sanción del impuesto provincial sobre carretas que transportaban carbón y madera para su extracción. Según lo establecido por el Reglamento de aduanas nacionales ${ }^{34}$ estas eran libres de derecho y, por lo tanto, su arancelamiento era un incumplimiento del artículo 10, capítulo 4 y título 14 del Estatuto de Hacienda. Sin embargo, negarse a cobrarlo significaba quebrantar una ley provincial y, por lo tanto, como receptor quedaba expuesto a ser acusado de defraudación al fisco. El nuevo administrador de la aduana nacional y receptor provincial del departamento de Rosario, Uladislao Frías, había mandado publicar la disposición en cumplimiento de su deber como oficial al mando de la Hacienda provincial, aunque no sin cierto resquemor. En su correspondencia con el colector general de la provincia expresaba así su preocupación:

En el presente creo, me encuentro con dos disposiciones contrarias, una de la provincia y otra de la nación, y con igual obligación de darles cumplimiento. En tal conflicto, he creído deber poner este asunto en conocimiento del exmo. Gobierno de la nación remitiendo la copia definitiva de usted a este, sin fin de que poniéndoles de acuerdo con el exmo. Gobierno de la provincia resuelvan lo que debe hacerse. Mientras tanto, para asegurar los decretos de la provincia, sin dejar de cumplir la ley nacional 35

El sinnúmero de cartas que desde la receptoría y aduana de Rosario se enviaban a la Contaduría de la Provincia y, desde allí, al Ministerio de Hacienda de la Confederación, muestra los obstáculos que debieron sortearse para homogeneizar las leyes fiscales. En las diferentes dependencias administrativas llovían solicitudes del personal demandando explicaciones sobre cómo proceder frente a las nuevas leyes nacionales: cuánto debían pagar las carretas que introducían artículos a

\footnotetext{
${ }^{33}$ Correspondencia del receptor del Rosario, don Francisco Carbonell, al colector general José Antonio Lassaga. Contaduría, t. 94, leg. 23, en AGSF.

34 RORA (1879), p. 49.

${ }^{35}$ Notas del administrador de aduana de Rosario, al contador general de la provincia. Contaduría, t. 97, leg. 5, en AGSF.
} 
la provincia; cuánto abonarían aquellas mercancías que estaban en los depósitos de la aduana, ingresadas bajo lo estipulado por la ley provincial y que ahora se hallaban regidas por el reglamento nacional. Había incertidumbre sobre qué reglamento aplicar al momento de recaudar los derechos de almacenaje y eslingaje ${ }^{36}$ Los mismos administradores dudaban respecto a cómo discriminar los ingresos nacionales de los provinciales, por lo que se emitió un comunicado que explicaba en detalle la forma de elaborar las planillas fiscales ${ }^{37}$

En pos de reordenar el funcionamiento de las oficinas se sancionó una serie de decretos. Una cuestión central para la correcta marcha administrativa era la conformación de un calendario fiscal. Los reglamentos para las aduanas y resguardos contenían los detalles de los plazos dentro de los cuales regían las tarifas, se depositaban las mercancías, se abonaban los gravámenes, se cancelaban las deudas, se pagaba los sueldos, así como los términos que debían cumplir los empleados para la entrega de las planillas (de consignaciones, de asientos, de sueldos, etc.) Se establecieron también los horarios en que debían permanecer abiertas las oficinas. Las dependencias públicas estaban obligadas a funcionar, al menos, cuatro horas diarias, aunque algunas las de policía -supeditadas a cualquier eventualidad y con guardia nocturna en caso de considerarse oportuno- y las aduanas que -debido a las operaciones de cargas, trasbordo y otras de esta naturaleza- tenían una franja horaria más extendida 39 De esta manera, los empleados vieron incrementados sus deberes y, de la mano del crecimiento del tráfico comercial, estuvieron obligados a mantener abierta las oficinas hasta "altas horas".

La gestión de los recursos de las aduanas recayó en manos de una administración que padecía todo tipo de limitaciones. Bajo la impronta del gobierno central, en un intento por remediar esta situación, las oficinas de aduanas y resguardos del puerto de Rosario -servidas por unos pocos empleados que cumplían con múltiples tareas- -40 aumentaron notoriamente su personal. Se creó el cargo de contador-interventor (encargado de elaborar las planillas de ingresos y egresos, y liquidaba las cuentas de la aduana y resguardo) y se consignó un ayudante para la oficina de contabilidad. Además, el incremento del tráfico comercial obligó a nombrar auxiliares para colaborar con las tareas del alcaide en la mesa de registro (al mando de los depósitos de la aduana, se encargaba de registrar las consignaciones, el número de bultos y el destino) y del vista en la capitanía del puerto (quien supervisaba las entradas y las salidas de mercancías del puerto) ${ }^{41}$ El capitán del puerto era, al mismo tiempo, comandante del resguardo y dependía del administrador de la aduana. Contaba con una partida celadora integrada por diez guardas que se ocupaba de rondar y vigilar las costas. Entre las tareas del comandante estaba el llevar una razón mensual de las personas que entraban

\footnotetext{
${ }^{36}$ Leyes y decretos, ceses y nombramientos y varias notas del ministro dirigida al colector general José A. Lassaga de todo el año 1853. Contaduría, t. 98, leg. 20, en AGSF.

${ }^{37}$ Nota del administrador de aduana del Rosario Uladislao Frías al colector general Cayetano Echagüe, dando explicaciones sobre los ramos que corresponden a la nación y a la provincia. Contaduría, t. 98, leg. 39, en AGSF.

${ }^{38}$ Registro Oficial de la Provincia de Santa Fe, 1980, t. 2, p. 37.

${ }^{39}$ Colección de varias leyes y decretos impresos, correspondientes al año 1853. Contaduría, t. 94, leg. 17, en AGSF.

${ }^{40}$ Tal es así que, por ejemplo, las funciones del capitán de puerto y del comandante del resguardo fueron asumidas por un único empleado al tiempo que, el administrador de aduanas ejerció de receptor de Hacienda y las tareas del vista las desempeñó el oficial primero de la receptoría. Órdenes y disposiciones del gobernador Estanislao López y de su delegado Pedro Larrechea al ministro de Hacienda José A. Lassaga en 1831, f. 636. Contaduría, t. 133, leg. 31, en AGSF.

${ }^{41}$ Nómina de los empleados de aduana. Resguardo administración de correos en la provincia de Santa Fe con especificación de sus servicios y aptitudes formadas en cumplimiento de la orden del señor ministro de Hacienda de la Confederación Argentina datada el 21 de noviembre de 1853. Contaduría, t. 94, leg. 30, en AGSF.
} 
y salían del puerto, así como supervisar todas las mercancías que transitaban por el mismo. La dificultad del resguardo para ejercer ambas tareas, vigilancia y control de mercancías obligó a las autoridades nacionales a descargar esta segunda tarea en la mesa de registro, dejando a los guardas la tarea de vigilancia 42

La capacidad y la eficacia de una administración para acometer sus tareas estaba condicionada, en parte, por sus posibilidades materiales (Whipple, 2013). Las oficinas de aduana y resguardo del puerto de Rosario mostraban una enorme desnudez. Su mobiliario se componía apenas de un armario donde se guardaban papeles y cuadernos, una única mesa que debía ser compartida por todo el personal de Hacienda y tres estantes donde se ubicaban los documentos. Contaba con una caja de fierro con dos llaves, una en poder del administrador y la otra del vista, donde se guardaba la recaudación. El archivo constaba de diferentes libros de registros: de permisos, de guías, de buques y de tropas de carga, el cuaderno para el cobro de derecho de piso y arrías, el cuaderno de pases expedidos, etc. También se salvaguardaban dos libros manuales, uno de los cuales quedaba en el archivo de la aduana y el otro era remitido al colector general, al menos mientras esta oficina dependió de la provincia ${ }^{43}$ Pese a la centralidad de sus aportes a las arcas fiscales, las condiciones materiales no se modificaron bajo la égida del gobierno central. La prensa local retrataba de forma irónica la situación:

- ¿Vamos ché? -¿Adónde? -Al calabozo. -Déjate de sonseras. -Pues yo voy en seguida, á abrir registro á un buque, y despachar unos permisos de introducción. -¿A la cárcel? -Si ó lo que es lo mismo a la Capitanía del Puerto. ¿No has visto esas decoraciones teatrales, que representan los calabozos de la inquisición o de la Bastilla? Pues bien, fíjate en la desnudes de esa oficina, y en la fúnebre pintura que la adorna 44

En el mismo espacio donde funcionaba la capitanía del puerto y la comandancia del resguardo se hallaba la receptoría de Rosario. Su ubicación fue una enorme ventaja en aquellos momentos en que los receptores estuvieron a cargo, al mismo tiempo, de la administración de la aduana. Sin embargo, cuando la aduana pasó definitivamente a jurisdicción nacional los problemas estuvieron a la orden del día. El receptor Pedro Lassaga se quejaba ante el colector general sosteniendo que "estando todo el archivo que me dejó el administrador saliente D. Frías en una pieza donde entran y salen 18 o 20 guardas no sería extraño la pérdida de algunos papeles, pues ya me he sucedido" 45 La solución que propuso para ello era muy sencilla: poner una puerta para separar ambas oficinas, la de receptoría y la de aduana, de modo tal que no se confundiesen los papeles, pero la medida no prosperó. No obstante, las dificultades obligaron a repensar la ubicación de la receptoría y trasladarla, finalmente, al edificio donde funcionaba la jefatura política. Una separación física que materializó la escisión definitiva de ambas esferas fiscales.

Las carencias materiales se reflejaron también en la insuficiencia de sueldos. Las autoridades debían procurar que el salario fuera suficiente para que los empleados dedicaran tiempo completo a esta actividad y, al mismo tiempo, alcanzara para compensar el trabajo y la responsabilidad que asumían en el ejercicio de su cargo. Las continuas peticiones elevadas por los propios empleados

${ }^{42}$ RORA (1879), pp. 113-118.

${ }^{43}$ Inventarios y balances de la aduana de Rosario por el administrador Uladislao Frías haciéndose cargo nuevamente Pedro Lassaga 1 de agosto de 1854. Contaduría, t. 97, leg. 17, en AGSF.

${ }^{44}$ El Patriota, 19 de enero de 1859.

${ }^{45}$ Notas del receptor de Hacienda de Rosario al contador general de la provincia. Contaduría, t. 97, leg. 39, AGSF. 
del departamento de Hacienda constituyen un claro reflejo de que los sueldos no alcanzaban a cubrir las necesidades mínimas. A principios de 1852 el oficial auxiliar de la receptoría de Hacienda de Rosario, Calixto Lassaga, se quejaba ante el gobernador:

[...] desde diciembre del año '44 estoy sirviendo de oficial auxiliar en la receptoría de este departamento, con una asistencia tan puntal y tan asidua trabajo, que no me queda tiempo ni el más mínimo, para contraerme a otra genero de industria. El sueldo, Exmo. señor, con que cuento por mi empleo, es el de 17 pesos mensuales, con él tengo que hacer frente a todas las necesidades de mi familia, no teniendo aun ni casa en que morar con una esposa y dos hijos 46

Estudios realizados sobre la composición de la canasta básica en Santa Fe compuesta de los cuatro productos básicos, a saber, pan, carne, azúcar y yerba, tenía un costo de 15.26 pesos (Frid, 2015). Si el sueldo del auxiliar de la receptoría era de 17 pesos quiere decir que una porción muy grande de su salario cubría sus gastos de alimento, sin dejarle margen para otras necesidades (vestimenta, alquiler, etc.). Es preciso considerar que los empleados de Hacienda "no viven más que de su sueldo", es decir no tienen otras actividades que les permita complementar sus ingresos. ${ }^{47}$

Las autoridades tanto provinciales como nacionales tenían muy presente que si todos aquellos encargados de manejar los caudales públicos no eran recompensados adecuadamente estarían tentados a proveerse de recursos con maniobras dudosas y, por lo tanto, la recaudación nunca estaría asegurada. Los salarios bajos podían empujar a los empleados a buscar compensaciones mediante la concurrencia a prácticas corruptas, desacreditando a la administración en su conjunto. En la carta de renuncia que eleva el receptor de Hacienda de Rosario, Fernando Carbonell, aseguraba "a la verdad Exmo Sr. Yo me hallo en un estado miserable de indigencia, y temo que esta me obligue a cometer algún fraude a la Renta del Estado para mantener mi familia" ${ }^{48}$ En el nombramiento de los empleados de Hacienda la confianza era clave. A fines de 1853, los peones de la aduana de Rosario exigieron un incremento de sueldo a 17 pesos mensuales, un salario muy por encima de los doce pesos que recibían entonces. No obstante, el administrador aconseja al gobierno cumplir con la demanda porque "hice llamar a otros peones, y aunque algunos pedían algo menos, no los he conchavado tanto porque no están acostumbrados al servicio que prestan los existentes, cuando porque los empleados no tenían confianza en ellos" ${ }^{49}$ Las quejas de los empleados de la aduana, el incremento del trabajo en estas oficinas y la necesidad de mantener un personal que inspire confianza del gobierno impulsaron el incremento de los salarios. Así el administrador de aduana pasó a cobrar 2000 pesos y el vista 1200 pesos (véase cuadro 7) 50

La otra cara del problema lo representaba la forma en que se abonaban los sueldos. Para 1853 el principal conflicto no radicó tanto en la demora de los libramientos como en el medio en que estos se pagaban. El papel moneda de la Confederación, el denominado papel de Fragueyro, inun-

\footnotetext{
${ }^{46}$ Correspondencia del contador general don José Lassaga al receptor del Rosario, Francisco Carbonell (Rosario, 24 de febrero de 1852). Contaduría, t. 90, leg. 7, en AGSF.

${ }^{47}$ Esta afirmación se constituyó en una fórmula muy presente en los pedidos de aumento de sueldo de los diferentes empleados de la provincia. Contaduría, t. 97, leg. 39; t. 94, leg. 13, en AGSF. Para un análisis sobre los salarios y los precios de Santa Fe remitimos, véase Frid (2016, 2017).

${ }^{48}$ Correspondencia citada por Córdoba Lutges (1969).

${ }^{49}$ Correspondencia del interventor don Gabriel López, y administrador de aduana de Rosario Uladislo Frías, dirigida al contador general don José Antonio Lassaga. Contaduría, t. 94, leg. 24, en AGSF.

${ }^{50}$ RORA (1879), p. 142.
} 


\section{GUADRO 7. SUELDOS DE LOS EMPLEADOS DE LA ADUANA Y RESGUARDO DEL PUERTO DE ROSARIO (1853)}

\begin{tabular}{lc}
\hline Empleado & Sueldo (anual) \\
\hline Administrador de aduana & 1200 \\
Contador interventor & 408 \\
Alcaide de aduana & 408 \\
Oficial de aduana & 300 \\
Vista & 600 \\
Oficial de la contabilidad & 408 \\
Auxiliares de aduana & 144 \\
Capitán de puerto & 720 \\
Dependiente del resguardo & 60 \\
\hline
\end{tabular}

Fuente: elaboración propia con base en Cámara de Diputados, t. 1, f. 491 (21 de noviembre de 1853), en Archivo Legislatura Provincial (ALP).

dó de forma repentina la provincia, ya que el gobierno nacional lo utilizó para pagar los sueldos atrasados del personal administrativo y militar. Su puesta en circulación generó gran malestar; los vecinos, acostumbrados a la moneda constante y sonante, se resistieron a recibirlos (Schmit, 2004). En Santa Fe los receptores de Hacienda se vieron obligados a persuadirlos de aceptar el papel a la par de la plata metálica. ${ }^{51}$ Igual resistencia opusieron los empleados de la aduana, quienes se negaban a cobrar sus sueldos en papel. Se emitieron distintas comunicaciones exigiendo que se tomaran las medidas pertinentes para obligarlos a consentir este medio de pago como una forma de demostrar que el personal de la administración de Hacienda participaba en el "espíritu del gobierno" 52 Pese a los esfuerzos, el demérito de este papel fue tal que el gobierno provincial dejó de utilizarlo para pagar los sueldos considerando injusto someter a los ciudadanos a recibir como pago billetes que "en nada podían utilizar" 53 La enorme resistencia encontrada en las provincias frenó la circulación y desde el gobierno central se resolvió dar marcha atrás y sacar los billetes de circulación 54

\section{CONCLuSión}

El proceso de conformación de la Confederación Argentina (1852-1862) primero, y el Estado nacional, más tarde, exigió nuevas articulaciones entre las jurisdicciones provincial y nacional. La Constitución nacional de 1853 decretó en su artículo 4 que el tesoro debía conformarse de tres fuentes de ingresos: las entradas de aduanas, las ventas de tierras fiscales y las rentas de correos. Además, debían considerase como ingresos los empréstitos que se tomaran y las operaciones de

${ }^{51}$ Notas de los jueces de paz de esta provincia (1854). Gobierno, t. 13, leg. 8, f. 906, en AGSF.

${ }^{52}$ Nota del administrador de Hacienda y Crédito nacional al contador de la aduana de Santa Fe. Contaduría, t. 97, leg. 26, en AGSF.

53 Notas del jefe político de Rosario al capitán. Contaduría, t. 97, leg. 21, en AGSF.

${ }^{54}$ Se ordenó suspender la emisión en septiembre de 1854 y retirarla de circulación en noviembre del siguiente año. A partir del 15 de febrero de 1856 quedó sin valor. Decretos del 22 de julio y 26 de septiembre de 1854 y 15 de noviembre y 17 de diciembre de 1855 . 
crédito. Las tierras baldías, muy numerosas y extensas, que podrían haber constituido una importante fuente de recursos, debido a que en la mayoría del territorio no habían sido aún enajenadas, se dejaron en manos de las provincias. Por otro lado, las rentas de correos fueron prácticamente insignificantes en el periodo. Se realizaron grandes esfuerzos por organizar una administración de correos que alcanzara a todo el territorio confederal, pero hasta la década siguiente las rentas en este ramo no tuvieron incidencia. Esta situación dejó a la confederación con un único recurso: las aduanas. Los gravámenes al comercio fueron los principales recursos del Estado. Ello representó para las provincias la pérdida de una porción -la más sustanciosa- de sus ingresos y una parte de sus administraciones de Hacienda.

Las aduanas y resguardos de puerto pasaron a jurisdicción nacional, aunque el proceso fue más pautado de lo que la legislación deja entrever. Durante 1852 y fines de 1854 la fiscalidad del Estado central continuó en manos de la provincia, no sin dificultades. Las sucesivas transformaciones de los reglamentos arancelarios fueron diagramando un nuevo orden fiscal al tiempo que delimitaron la política impositiva. Sin embargo, el proceso de diferenciación de ambas potestades no siempre fue transparente, subsistieron zonas grises tal como lo demuestra la insistencia de las autoridades locales en cobrar un impuesto a las carretas que circulaban en el territorio, lo que no era más que una contribución indirecta encubierta.

Construir un entramado administrativo que permitiese al gobierno central hacerse con los recursos conllevó marchas y contramarchas como sucedió con la experiencia de la Administración de Hacienda y Crédito y el Banco Nacional. Inaugurados a inicios de 1854 sólo funcionaron unos pocos meses, pues en septiembre de ese mismo año fueron disueltos. Idéntica suerte corrió la reforma monetaria, aunque en teoría debía contribuir a aliviar las presiones fiscales y solventar los gastos de la administración, su puesta en práctica no cosechó los resultados esperados. A las resistencias de la población a aceptar el papel moneda se le sumó la falta de liquidez fiscal. Los billetes carecían de fondos de garantía debido a que la banca nacional no contaba con dinero metálico para respaldar las emisiones. Las autoridades nacionales confiaban que la entrada permanente de efectivo contribuiría a preservarlas y se cubriría cualquier déficit, pero ello no ocurrió. Así poco tiempo después los billetes fueron sacados de circulación.

A partir de 1855 con la nacionalización definitiva de los recursos de las aduanas y sus oficinas convertidas en Contaduría General de la Nación, la provincia de Santa Fe, al igual que las restantes, se vieron obligadas a imponer nuevas pautas legales reestructurando sus sistemas de recaudación. La nueva política tributaria debía afirmarse en los postulados que desde el ámbito nacional se propulsaban -a saber, equidad, universalidad y obligatoriedad-. Las autoridades provinciales, entonces, se volcaron a la tarea de crear nuevas figuras fiscales para robustecer sus arcas. En el caso de Santa Fe, la sanción de leyes impositivas constituyó el primer paso para regular el erario. Su aprobación conllevó arduas discusiones en el interior de la Asamblea Legislativa en torno a la manera de imponer los arbitrios. Los debates revelan la enorme preocupación de los legisladores por cumplir con un requisito fundamental: respetar la potestad fiscal del Estado nacional.

\section{LisTA DE REFERENCIAS}

Alberdi, J. B. (1854). Sistema económico y rentístico de la Confederación Argentina: según la Constitución de 1853. Buenos Aires: El Foro.

Álvarez, J. (1929). Temas de historia económica argentina. Buenos Aires: El Ateneo.

Álvarez, J. (1943). Historia de Rosario (1689-1939). Rosario: Universidad Nacional de Rosario. 
Álvarez, J. (1946). Guerra económica entre la Confederación y Buenos Aires (1852-1861). En R. Levene (ed.), Historia de la nación argentina (pp. 67-109). Buenos Aires: Academia Nacional de la Historia.

Ayrolo, V., Lanteri, A. L. y Morea, A. (2011). Repensando la carrera de la revolución. Aportes a la discusión sobre las trayectorias políticas entre la revolución y la Confederación (Argentina, 1806-1861). Estudios Históricos-CDHRP, 3(7), 1-28.

Bonaudo, M. (2006). La organización productiva y política del territorio provincial (1853-1912). Nueva Historia de Santa Fe. Rosario: Prohistoria/La Capital.

Bragoni, B. y Míguez, E. J. (eds.). (2010). Un nuevo orden político: provincias y Estado nacional, 1852-1880. Buenos Aires: Editorial Biblos.

BREwer, J. (1994). The sinews of power: war, money, and the English State, 1688-1783. Londres: Routledge.

Buchisnder, P. (2004). Caudillos de pluma y hombres de acción: estado y política en Corrientes en tiempos de la organización nacional. Los Polvorines [Argentina]. Buenos Aires: Universidad Nacional de General Sarmiento/Prometeo Libros.

Carrasco, G. (1900). Registro estadístico de la población de la Provincia de Santa Fe con sujeción al Censo Oficial levantado en abril de 1858 bajo la dirección de Juan José Gormaz y Carreras. Buenos Aires: s. e.

Chiaramonte, J. C. (1993). El federalismo argentino en la primera mitad del siglo xix. En M. Carmagnani y G. J. Bidart (eds.), Federalismos latinoamericanos: México, Brasil, Argentina (pp. 81-132). México: El Colegio de México-Fideicomiso Historia de las Américas/Fondo de Cultura Económica.

Chiaramonte, J. C. (ed.) (1997). Ciudades, provincias, Estados: orígenes de la nación argentina (18001846). Buenos Aires: Ariel.

Chiaramonte, J. C., Cussianovich, G. y Tedeschi, S. (1993). Finanzas públicas y política interprovincial: Santa Fe y su dependencia de Buenos Aires en tiempos de Estanislao López. Boletín del Instituto de Historia Argentina y Americana Dr. Emilio Ravignani, 8, 77-116.

Collins, J. B. (1997). State Building in Early-Modern Europe: the Case of France. Modern Asian Studies, 31(03), 603-633. Dor: 10.1017/S0026749X0001708X

Córdoba, M. (1969). Origen y evolución del correo en Rosario. Revista de Historia de Rosario, 5 , $15-16$.

Djenderedjian, J. y MartiRén, J. L. (2012). La distribución de la riqueza rural entre tradición y modernidad. Los casos de la colonia Esperanza y el distrito de Paraná durante la década de 1860. Población EO Sociedad, 19(2), 125-154.

FRID, C. (2012). Producción agraria y crecimiento económico en el sur de Santa Fe (1840-1860). En C. FRid y N. S. LANciotti (eds.), De la expansión agraria al desarrollo industrial: la economía de Santa Fe entre 1850 y 1970 (pp. 17-48). Rosario: Prohistoria Ediciones.

FRID, C. (2015). Salarios, precios y desigualdad en Santa Fe (1820-1850). Presentado en Vigésimas Jornadas Investigaciones en la Facultad de Ciencias Económicas y Estadísticas, Buenos Aires: Universidad Nacional de Rosario.

FRID, C. (2016). La evolución de los salarios en una economía en crisis: Santa Fe en la primera mitad del siglo xIx. XV Congreso de la Sociedad Española de Historia Agraria/V Encuentro Rural RePort, Lisboa.

Frid, C. (2017). Precios y crisis en una economía rioplatense. Santa Fe (1790-1850). América Latina en la Historia Económica, 24(2), 59-92. Dor: 10.18232/alhe.v24i2.746 
Gallo, E. (1965). Santa Fe en la segunda mitad del siglo XIX. Transformaciones en su estructura regional. Anuario del Instituto de Investigaciones Históricas de la Universidad Nacional del Litoral, 7, 27-60.

Garavaglia, J. C. (2010a). Algunos aspectos preliminares acerca de la "transición fiscal” en América Latina, 1800-1850. Illes i Imperis, 13, 159-192.

Garavaglia, J. C. (2010b). Rentas, deuda pública y construcción estatal: la Confederación Argentina, 1852-1861. Desarrollo Económico, 50(198), 223-248.

Garavaglia, J. C. (2016). La disputa por la construcción nacional argentina. Buenos Aires, la Confederación y las provincias (1850-1865). Buenos Aires: Prometeo.

Garavaglia, J. C., Pro Ruiz, J. y Zimmermann, E. (eds.). (2012). Las fuerzas de guerra en la construcción del Estado: América Latina, siglo XIX. Rosario: Prohistoria.

Gschwind, J. (1927). Diplomacia y política económica de la Confederación 1852-1862. Rosario: Isach Ferrer Hermanos.

Halperín, T. (ed.) (2005). Guerra y finanzas un cuarto de siglo después. En Guerra y finanzas en los orígenes del estado argentino, 1791-1850 (pp. 9-14). Buenos Aires: Prometeo.

Herrera, C. (2010). Fiscalidad y poder: las relaciones entre el estado tucumano y el estado central en la formación del sistema político nacional, 1852-1869. En B. Bragoni y E. J. Míguez (eds.), Un nuevo orden político. Provincias y Estado Nacional 1852-1880 (pp. 181-207). Buenos Aires: Biblos.

Irigoin, M. A. (2003). La fabricación de moneda en Buenos Aires y Potosí y la transformación de la economía colonial en el Río de la Plata (1820 y 1860). En M. A. IRIGorn y R. Schmit (eds.), La desintegración de la economía colonial: comercio y moneda en el interior del espacio colonial (18001860) (pp. 57-91). Buenos Aires: Biblos.

Jáuregui, L. (2010). México: la experiencia de las participaciones federales en el siglo XIX. Illes $i$ Imperis, 13, 137-157.

LANTERI, A. L. (2013a). Acerca del aprendizaje y la conformación político-institucional nacional. Una relectura de la "Confederación” argentina (1852-1862). Secuencia, 87, 69-94. DoI: 10. 18234/secuencia.v0i87.1205

LANTERI, A. L. (ed.). (2013b). Actores e identidades en la construcción del estado nacional: Argentina, siglo XIX. Bueno Aires: Editorial Teseo.

Marichal, C. y Marino, D. (eds.). (2001). De colonia a nación: impuestos y política en México, 17501860. México: El Colegio de México.

Mega, A. (2010). La Confederación Argentina (1852-1861), ¿un proyecto institucional trunco? Hablemos de Historia, 6, 195-207.

Nicolini, E. A. y Parolo, M. P. (2009). La circulación de moneda en el norte argentino después de la independencia: el caso de Tucumán entre 1820 y 1850. Revista de Historia Económica/Journal of Iberian and Latin American Economic History, 27(1), 75-102. Dor: 10.1017/ S0212610900000719

O’Brien, P. K. O. y Hunt, P. A. (1993). The Rise of a Fiscal State in England, 1485-1815. Historical Research, 66(160), 129-176. DOI: 10.1111/j.1468-2281.1993.tb01806.x

Pantoja, D. (2007). Infancia es destino: el federalismo y las finanzas públicas nacionales en el Congreso Constituyente de 1824. Revista Mexicana de Ciencias Políticas y sociales, 49(201), 85109. DOI: $10.22201 /$ fcpys.2448492xe.2007.201.42592

Registro Oficial de la Provincia de Santa Fe (1890). Santa Fe: Tipografía de la Revolución. 
Registro Oficial de la República Argentina que comprende los documentos expedidos desde 1810 hasta 1873 [RORA], t. 3: 1852-1856 (1879). Buenos Aires: Imprenta La República.

Rex, S. (2004). La fiscalidad provincial entre la Constitución y el despegue azucarero. Tucumán, 1852-1876. América Latina en la Historia Económica, 11(1), 119-139. Dor: 10.18232/alhe. v11i1.338

Ríos, E. DE LOS (2017). Gobernar es cobrar. Política fiscal, recaudación impositiva y cultura tributaria. Santa Fe (Argentina, 1855-1873). Rosario: Prohistoria.

Romano, S. (1992). Finanzas públicas de la provincia de Córdoba 1830-1855. Boletín del Instituto de Historia Argentina y Americana Dr. Emilio Ravignani, 5, 99-147.

SÁnchez, E., JÁuregui, L. e IbARRA, A. (eds.) (2001). Finanzas y política en el mundo iberoamericano: del antiguo régimen a las naciones independientes, 1754-1850. México: Instituto de Investigaciones Dr. José María Luis Mora.

Schaller, E. (2001). El papel moneda en la provincia de Corrientes (1841-1863) (vol. 2, pp. 895-925). Presentado en Encuentro de Geohistoria Regional.

Schaller, E. (2002). Las finanzas públicas de Corrientes durante la organización constitucional (1851-1861). Revista Nordeste, 16, 5-33.

Schmit, R. (2004). Ruina y resurrección en tiempos de guerra. Sociedad, economía y poder en el oriente entrerriano posrevolucionario, 1810-1852. Buenos Aires: Prometeo.

Scobie, J. (1964). La lucha por la consolidación de la nacionalidad. Argentina, 1852-1862. Buenos Aires: Hachette.

Storrs, C. (ed.) (2009). The fiscal military state in eighteenth-century Europe: essays in honour of P. G. M. Dickson. Surrey: Ashgate. Recuperado de http://www.tandfebooks.com/isbn/9781315558110

Tilly, C. (1990). Coercion, capital, and European States, A.D. 990-1992. Oxford: Basil Blackwell.

Whipple, P. (2013). Carencias materiales, respetabilidad y prácticas judiciales en Perú durante los inicios de la República. Historia Crítica, 49, 55-79.

Archivos

Agsf Archivo General de la Provincia de Santa Fe, Santa Fe, Argentina.

ALP Archivo Legislatura Provincial, Santa Fe, Argentina.

NA National Archives, Public Record Office, Foreing Office, Londres, Reino Unido. 